Review

\title{
A Review on Electric Traction using WE System
}

\author{
Anurag Dwivedi, Dhananjay Kumar and Nitesh Tiwari \\ Department of Electrical Engineering KIPM CET, GIDA, Gorakhpur India
}

Article history

Received: 15-04-2019

Revised: 19-04-2019

Accepted: 04-05-2019

Corresponding Author:

Anurag Dwivedi

Department of Electrical

Engineering KIPM CET,

GIDA, Gorakhpur India

Email: anurag.srmcem007@gmail.com

\begin{abstract}
In this analysis, the recent trend the generated renewable source energy (like wind energy) utilized the traction system. Present a limited conventional source. Environment pollution by the burning of diesel fuel will be increased. And the using wind energy source controls the pollution and efficiency will be increased. In this process, the wind energy system is connected to the network and synchronized frequency by the power grid. Grid supply to the locomotives load for (traction system). The power applied off the $25 \mathrm{KV}$. This system used very high voltage and bear on high power. Almost renewable energy source use of the traction system near about eight percent in India. Locomotives use the DC motor. A doubly fed induction generator is used for converting wind energy to electrical energy.
\end{abstract}

Keywords: Wind Energy System (WES), Renewable Source Energy (RSE), Traction Power Supply System (TPSS), Indian Railway (IR)

\section{Introduction}

Indian Railways are using electric traction system by $25 \mathrm{KV}$ system (Hughes et al., 2005). This system is most useful with high power and high voltage (Prats et al., 2006). Day by day growth load demand in this system. Limited Availability of conventional source and pollution due to the utilization in the fuel Renewal energy source (Liserre et al., 2006). Using wind energy system with the grid system (Adel Tabakhpour et al., 2014). Attach to traction advance. Electricity System load with help off supplied power locomotive (Vaishnav et al., 2016). Railway Reportedly doing commissioning project in JAISALMER Of 26MW (Hughes et al., 2005; Adel Tabakhpour et al., 2014; Kincha et al., 2004). By the Railway Energy Management Company (REMC) by the Indian railway. Wind energy has utilized a form of Renewable energy source clean energy (Bhuvaneswari et al., 2006). Such modern electricity of traction power. Supply system and renewable energy. Source it is looking forward to a renewable energy source (Hill, 1994). Like wind and solar energy. This source Present a huge amount and not ended source (Hill, 1994). Development of the locomotive load and these result in need Traction Power supply System (TPS) (Sheshadri et al., 2004). Renewable energy source Connected to grids interfacing of the distributed generation system to the development Power (De Gusseme et al., 2008). Alternative current source or DC source. Supply rectified by a half control rectifier converter (Prats et al., 2006). In this research
Paper for regenerative energy utilization. Is summarized not only in DC railway but also AC railway (Jenkins et al., 2005). Railway traction system has efficiency is very high (Kale et al., 2014). And low Pollution This Generally (RTS) started in the 20century (Liserre et al., 2006). Load demand increases every day. So it is the connection (RTS) like Wind energy (Adel Tabakhpour et al., 2014). Non-conventional energy source. That is diesel, coal steam in the limited in my country (Bhuvaneswari et al., 2006; Celli, G., S.B. Tennakoon and F. Pilo, 2000; Adel Tabakhpour et al., 2014; Kale et al., 2014).

So, wind energy has clean and green. The energy of using the traction system (Kale et al., 2014). In this conclusion steam in the limited in my country network as an (RSE) (Thomas et al., 2013).

Doing the following step:

1. Wind energy at the DC power Source provided (Prats et al., 2006)

2. Wind energy supplies the Traction system (Kincha et al., 2004)

3. Interconnected power is used by substation to run locomotive (Sheshadri et al., 2004)

The local government considers the renewal energy Source and (TPS) (Mazouz et al., 2017; Jenkins et al., 2005). This network root of handling the energy (RSE) with wind energy (Adel Tabakhpour et al., 2014). 


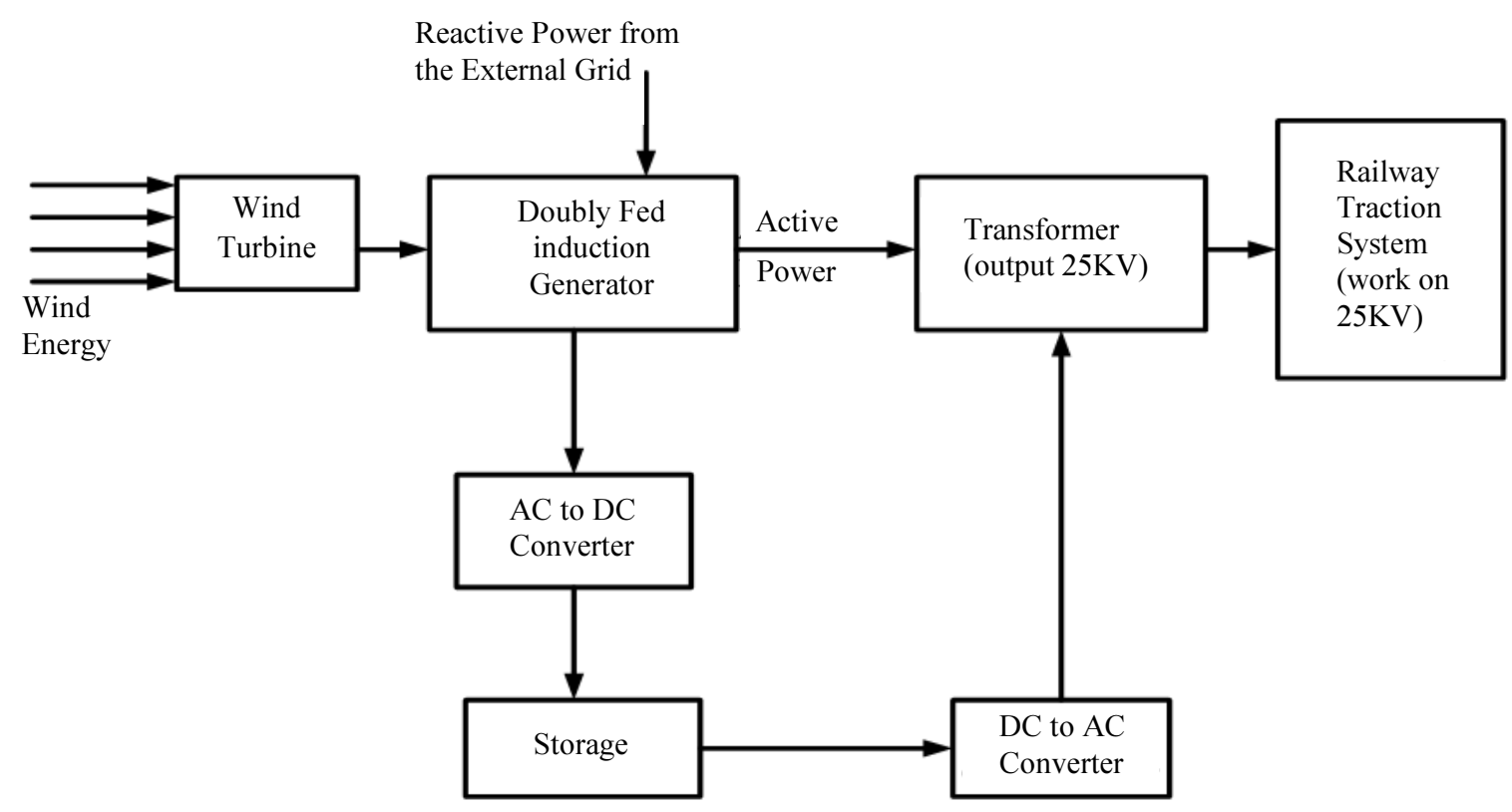

Fig. 1: The Methodology used For Power Transfer Scheme from Wind Turbine to Railway Traction

Conversion system beyond the traditional wind miles (Maheshwari and Bhalja, 2007). And (S) using DC series motor has required to the high torque in the locomotive energy power (Lozano et al., 2010). And wind power connected the bridge supply (De Gusseme et al., 2008). By the synchronizing method and Frequency will be same of both the power Station (Kale et al., 2014). Alternating current (TPS) given AC from over headline in Given the wind energy by (RSE) (Thomas et al., 2013). (RTS) large distance is very cheaper (Kumar and Singh, 2014).

\section{Methodology}

This paper is basically focused on the power transfer Scheme from wind energy to the traction system of the railway. In the wind-based generation generally, Doubly Fed Induction Generator (DFIG) is used which is not able to generate reactive power itself. So reactive power need to supply from the external grid and DFIG will generate active power that's fed as output.

In India, railway traction system is working on $25 \mathrm{KV}$ grid system so a transformer is required to supply this rating power. When the traction system has not demanded the supply then power generated by this system is stored into the different storing system as shown in Fig. 1.

\section{Renewable Energy Source}

Renewal energy source that supplies power in wind energy (Hughes et al., 2005; Liserre et al., 2006; Adel Tabakhpour et al., 2014). Wind energy source future prospective needs high electric power (Kumar and Singh, 2014). The railway traction system is a very useful source. Wind energy (Xuesong et al., 2010). Solar energy in the presence of very large amount (Elgendy et al., 2013). Supply this source (RSE) produce the power supply and Interconnected (RSE) (Ramki and Tripathy, 2015). Of the wind energy is the grid network is a renewable energy source (Dash et al., 2014) energy has a railway choice have a good option (Thomas et al., 2013) Indian railway as setting up in Lithuania Railway Station (Hughes et al., 2005; Liserre et al., 2006; Bhuvaneswari et al., 2006). Wind energy is good to choose the traction System (Bhuvaneswari et al., 2006). It uses the large benefit of the traction system. Renewable energy source uses the most useful. And provide the increase the efficiency and decrease or Control the pollution on the atmosphere.

\section{Describe the Wind Energy Conversion System}

Renewable energy source links up to grid user Interface via DC current above figure (Maheshwari and Bhalja, 2007). Power generation system Energy convert (Lozano et al., 2010). It is a Dominant component and connected to the energy source (Kale et al., 2014). RES applied to the grid and Converted power (RSE) should be Alternative current Source OR Direct current source (Thomas et al., 2013). Convert fixed to DC link wind energy generated. Variable AC voltage Power Improvement link on DC link (Kumar and Singh, 2014) is shown in Fig. 2. 


\section{Locomotive Traction System with R.S.E.} System

As Per the average natural of the wind energy global warming have to do (Esram and Chapman, 2007). With worry somebody. Use of source Contributed in
India than very large and renewable energy huge amount of in percentage India (De Gusseme et al., 2008). So clean and green Energy Depending on the system by lay out (Ramki and Tripathy, 2015). (RSE) Power supply to the interconnected to Transfer to the grid (Coelho et al., 2009).

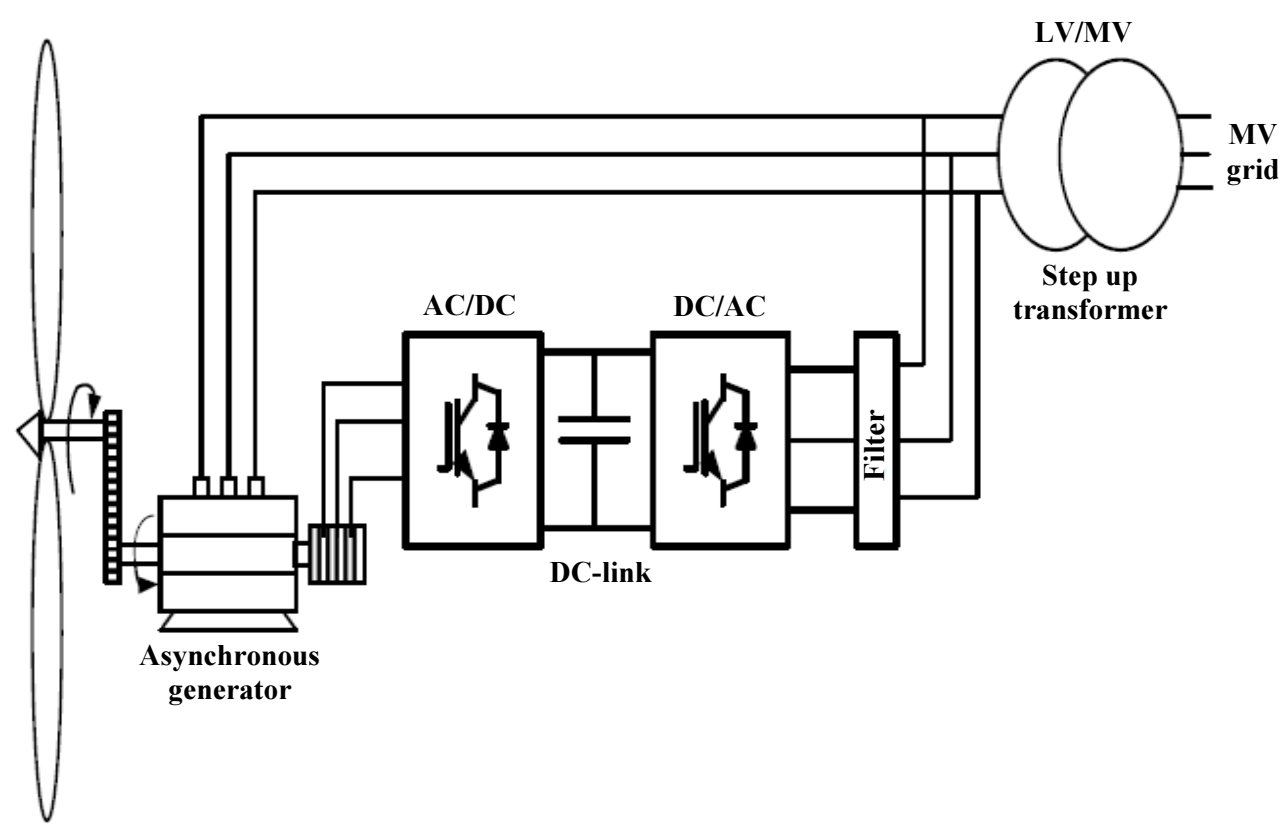

Fig. 2: Wind energy system

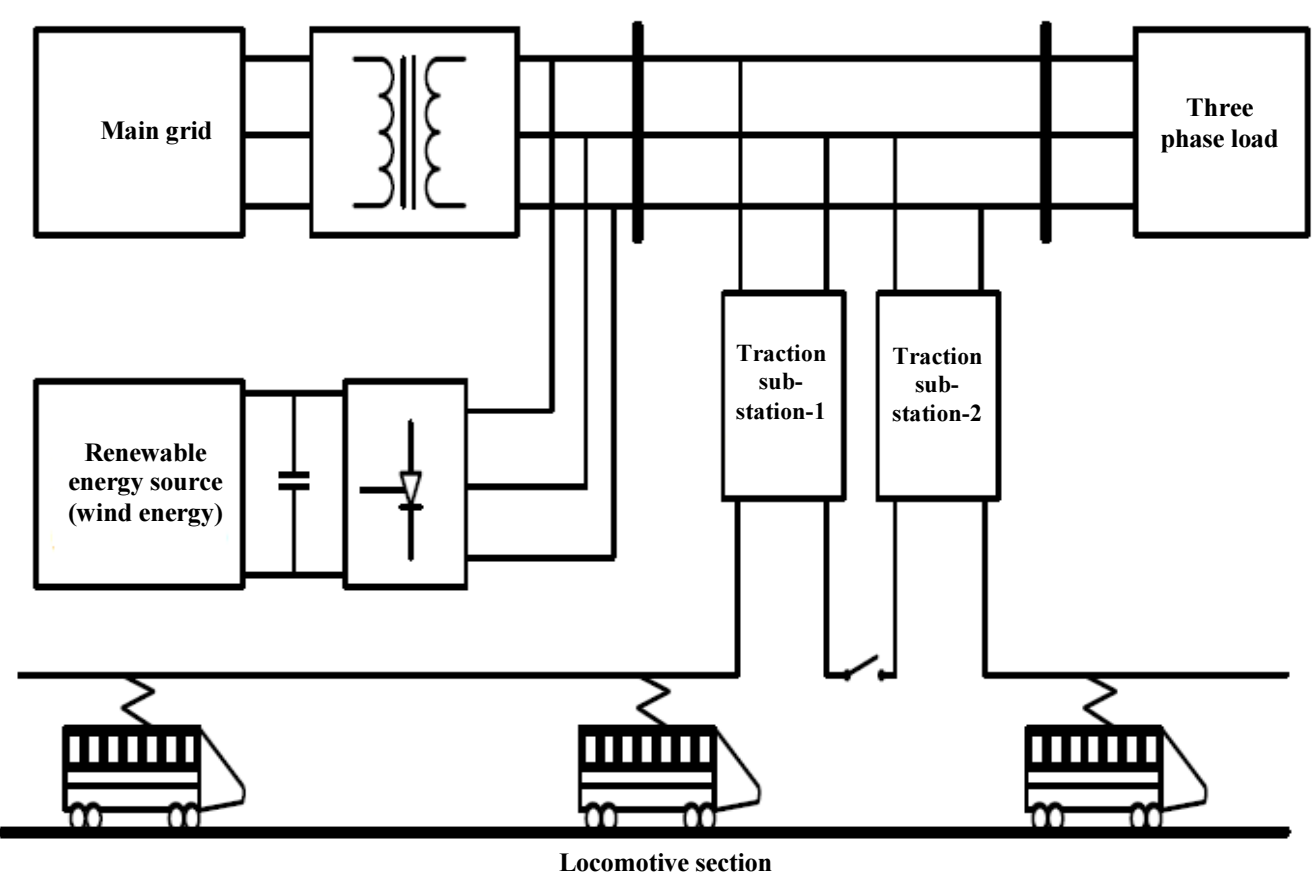

Fig. 3: Power transfer scheme from hybrid grid to railway traction system 
Wind energy RSE System regularly produces the energy in Nature, (De Gusseme et al., 2008). Renewable energy source act (Coelho et al., 2009; Mazouz et al., 2017). As an AC source grid connected With something in the Way (port) .important role (Jenkins et al., 2005; Dash et al., 2014). Of the Component of the power, electronic source Developed the fast working and utilized the (RSE) (Thomas et al., 2013). To the system the base grid. The turbine of the wind-related to the generator and developed to the energy (Liserre et al., 2006; Kale et al., 2014). And connected to the transformer and marge to three-phase power System (Tibor et al., 2011). System grid and synchronized the frequency of the grid supply (Veeraraghavan et al., 2014; Dash et al., 2014). As the Dissimilar of the more locomotive load (Coelho et al., 2009), like diesel, each other which slowly result to use the electric railway system (Jenkins et al., 2005; Lozano et al., 2010).

It is called a traction power system Railway Traction Power Supply System (RTPSS). Indian railway already used in electric has been $25 \mathrm{kV}$ (De Gusseme et al., 2008). Applied to the traction system. Sub-station of (IR) network (Jenkins et al., 2005; Veeraraghavan et al., 2014). Study of power specification general India railway (Prats et al., 2006). Substation so is some rating each supply $220 \mathrm{kV} 50 \mathrm{~Hz}$ as Fig. 1. In traction system used in DC series motor. As run as a run resistance control (Kincha et al., 2004). Than Speed increases association (Kale et al., 2014). Of the Switch series to parallel D, supply is still better to use (Thomas et al., 2013). Basic Element of distributed generation System as the joint the Renewable energy to the power of the grid is expanded to the Supply. This system is shown in Fig. 3.

\section{Transformer and Rectification Substation}

In general purpose, supply has been concern $t$ to run Electric train admin only three-phase powers supply single or two-phase power supply. Single phase waste of the three-phase supply neglected The Unbalance system feeding the two-phase at Change the Part by part each to $\mathrm{A}-\mathrm{B}, \mathrm{c}-\mathrm{c}$ and proper Locomotive is provided to each other system Balance.

\section{Locomotive Design}

Train wagon s series of the traction system $2.5 \mathrm{MW}$ for DC model in the proper use of a step-down transformer in the system $25 \mathrm{KV}$. To. $750 \mathrm{v}$ two half rectifier. Traction system connected of a train engine and wagons Series use of the transformer in a step down in traction system Voltage converted $25 \mathrm{KV}$ two half control SCR with Freewheeling rectifiers. Wind energy Produce the AC/DC source Converted to the fixed. Steam Link turbine developed to the variable alternating.

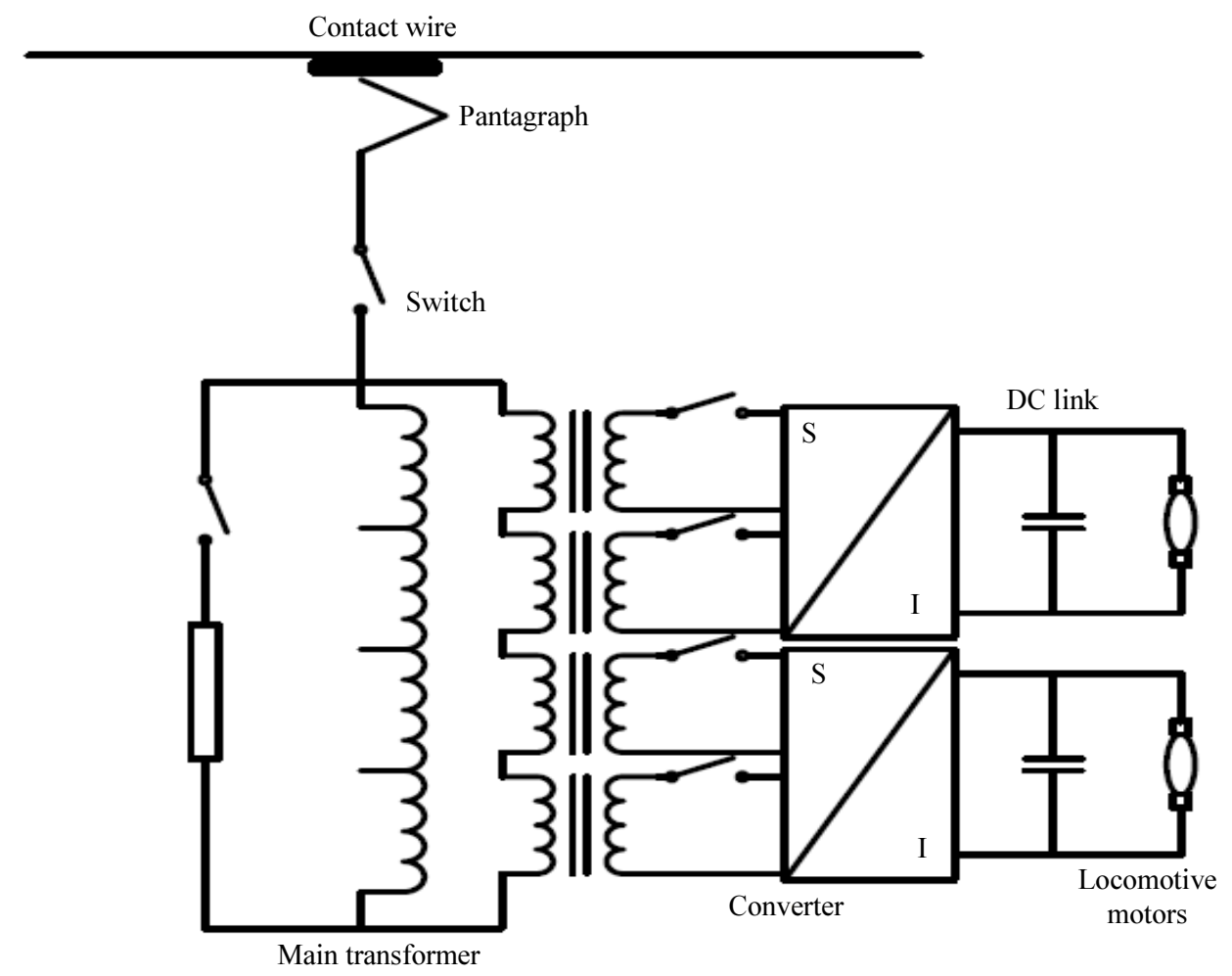

Fig. 4: Representation of traction supply to the locomotive 
Current and voltage divided the capacitor from the grid and change the product the power to grid wind energy system type of Renewable energy system. Current source feeding energy conversion system with the synchronizing the frequency. In India have Different technology uses in the railway traction system and different. Different source so high Speed and very highefficiency .losses and maintenance Will be low in the traction system. Provide efficiency is very high. This system is sown in Fig. 4.

\section{Link}

Change capacitor has a use for. Maintain across the DC motor in the DC links. The capacitor will almost change but no change the balance across the traction system in motor in the DC link supply with the traction system.

\section{Type of Storage System}

Storage system generally applied to reference in particular load. Power is not distribution proper way also for improve. The caliber of generating power wind power system uses the most important method for energy storage has renewable Source energy. Wide-scale general considers as energy .system so air is not blowing at energy at same location use of the standard method.

\section{Flywheels}

The flywheel of a most important element of mechanical device. This application to collect the kinetic energy Of a relationship mass. Traction system fit use In 20 -year ago use flywheel. It is boundary of power generation OR DC motor assemble Set.

First priority class consist of steed rotor renewable energy speed low near about (6000 rpm).

The flywheel of manufacturing in the modern composition material .because if increase the higher efficiency has of advanced methods of the increase the high speed.

\section{A. Advantage}

1. more economical

2. Less energy Consumption

3. Environment friendly

4. Less noise and pollution

\section{B. Limitation}

1. Required completed circuitry

2. Required highly skilled and Trains operators

3. Required more research

\section{Conclusion}

This paper analyzing important technique inter Connected Renewable energy source of in Using wind energy with traction system use of (RSE) energy of green energy less Pollution in the environment and efficiently high In (TP) with help of synchronized the Grid. And in this research is very reliable and produced about the output waveform Torque speed it is more efficient Comparison than other source traction system like (distal). This technic utilized Wind turbine, DFIG, converter, and other basic resources to make Electric Traction using wind energy System for Indian railway.

\section{Acknowledgment}

The author would like to express a gratitude to their co-author and his team members, for the support, belief, patience, fairness and for the feedback. The author would like to thank him for the opportunities and knowledge that he has given to the author over the year.

\section{Author's Contributions}

Dr. Anurag Dwivedi is Coordinated the data-analysis, contributed to the writing of the manuscript, designed the research plan, and organized the study. Mr. Dhananjay Kumar is Contributed to the writing of the manuscript and coordinated the mouse work. Er. Nitesh Tiwari is Coordinated the data-analysis, contributed to the writing of the manuscript, designed the research plan, and organized the study.

\section{Ethics}

Authors should address any ethical issues that may arise after the publication of this manuscript.

\section{References}

Adel Tabakhpour, L., S.M.G. Mousavi, E.F. Fuchs and K. Al-Haddad, 2014. Power quality issues in railway electrification: A comprehensive perspective. IEEE Trans. Indust. Electr., 62: 3081-3090. DOI 10.1109/TIE.2014.2386794

Bhuvaneswari, G., B. Singh and V. Garg, 2006. Improved power quality AC-DC converter for electric multiple units in electric traction. Proceedings of the IEEE Power India Conference, Apr. 10-12, IEEE Xplore Press, New Delhi, India, pp: 6-6. DOI: 10.1109/POWERI.2006.1632486

Celli, G., S.B. Tennakoon and F. Pilo, 2000. Voltage regulation on $25 \mathrm{kV}$ AC Railway systems by using thyristor switched capacitor. Proceedings of 9th International Conference on Harmonics and Quality of Power, Oct. 1-4, IEEE Xplore Press, Orlando, FL, USA, pp: 633-638.

DOI: 10.1109/ICHQP.2000.897752 
Coelho, R.F., F. Concer and D.C. Martins, 2009. A study of the basic DC-DC converters applied in maximum power point tracking. Proceedings of the Brazilian Power Electronics Conference, Sep. 27-Oct. 1, IEEE Xplore Press, Bonito-Mato Grosso do Sul, Brazil, pp: 673-678. DOI: 10.1109/COBEP.2009.5347723

Dash, S.K., D. Verma, S. Nema and R.K. Nema, 2014. Comparative analysis of Maximum Power Point (MPP) tracking techniques for solar PV applications using MATLAB Simulink. Proceedings of the IEEE International Conference on Recent Advances and Innovations in Engineering, May 9-11, IEEE Xplore Press, Jaipur, India, pp: 1-7. DOI: 10.1109/ICRAIE.2014.6909110

De Gusseme, K., L. Vandevelde, K. Stockman, M.H.J. Bollen and B. Renders et al., 2008. Distributed generation for mitigating voltage dips in low-voltage distribution grids. IEEE Trans. Power. Del., 23: 1581-1588. DOI: 10.1109/TPWRD.2007.916162

Elgendy, M.A., B. Zahawi and D.J. Atkinson, 2013. Assessment of incremental conductance maximum power point tracking algorithm. IEEE Trans. Sustainable Energy, 4: 108-117.

DOI: $10.1109 /$ TSTE.2012.2202698

Esram, T. and P.L. Chapman, 2007. Comparison of photovoltaic array maximum power point tracking techniques. IEEE Trans. Energy Convers., 22: 439-449. DOI: 10.1109/TEC.2006.874230

Hill, R.J., 1994. Electric railway traction. Part 3. Traction power supplies. Power Eng. J., 8: 275-286. DOI: $10.1049 /$ pe: 19940604

Hughes, F.M., O. Anaya-Lara, N. Jenkins and G. Strbac, 2005. Control of DFIG-based wind generation for power network support. IEEE Trans. Power Syst., 20: 1958-1966. DOI: 10.1109/TPWRS.2005.857275

Jenkins, N., G. Strbac and O. Anaya-Lara, 2005. Control of DFIG-based wind generation for power network support. IEEE Trans. Power Syst., 20: 1958-1966. DOI: 10.1109/TPWRS.2005.857275

Kale, V.S., G.C. Sekhar and G.V. Krishna, 2014. Application of SVC to improve voltage profile of Indian railway traction system. Proceedings of the IEEE International Conference on Power Electronics, Drives and Energy Systems, Dec. 1619, IEEE Xplore Press, Mumbai, India, pp: 1-5. DOI: 10.1109/PEDES.2014.7041968

Kincha, H.P., K.G. Sheshadri, K. Parthasarathy, D. Thukaram and U.J. Shenoy, 2004. A real-time DSP based quadrilateral relay for distance protection of $25 \mathrm{kV}$ AC traction overhead equipment. Proceedings of the International Conference on Power System Technology, Nov. 21-24, IEEE Xplore Press, Singapore, pp: 1339-1344.

DOI: 10.1109/ICPST.2004.1460209
Kumar, R. and B. Singh, 2014. Buck-boost converter fed BLDC motor drive for solar PV array based water pumping. Proceedings of the IEEE International Conference on Power Electronics, Drives and Energy Systems, Dec. 16-19, IEEE Xplore Press, Mumbai, India, pp: 1-6.

DOI: 10.1109/PEDES.2014.7042001

Liserre, M., F. Blaabjerg, A.V. Timbus, R. Teodorescu and F. Blaabjerg, 2006. Overview of control and grid synchronization for distributed power generation systems. IEEE Trans. Indust. Electr., 53: 1398-1409. DOI: 10.1109/TIE.2006.881997

Lozano, J., J. Felez, J.M. Mera and J.D. Sanz, 2010. Using bond-graph technique for modeling and simulating railway drive systems. Proceedings of the 12th International Conference on Computer Modelling and Simulation, Mar. 24-26, IEEE Xplore Press, Cambridge, UK, pp: 444-449. DOI: 10.1109/UKSIM.2010.88

Maheshwari, R.P. and B. Bhalja, 2007. High speed protection scheme for traction OHE of $25 \mathrm{kV} \mathrm{AC}$ Indian railway system. Proceedings of the IEEE Industry Applications Annual Meeting, Sept. 23-27, IEEE Xplore Press, New Orleans, LA, USA, pp: 904-910. DOI: 10.1109/07IAS.2007.141

Mazouz, F., S. Belkacem, Y. Harbouche, R. Abdessemed and S. Ouchen, 2017. Active and reactive power control of a DFIG for variable speed wind energy conversion. Proceedings of the 6th International Conference on Systems and Control, May 7-9, IEEE Xplore Press, Batna, Algeria, pp: 27-32. DOI: 10.1109/ICoSC.2017.7958642

Prats, M.Á.M., J.T. Bialasiewicz, L.G. Franquelo, J.I. León and J.M. Carrasco et al., 2006. Powerelectronic systems for the grid integration of renewable energy sources: A survey. IEEE Trans. Indust. Electr., 53: 1002-1016. DOI: $10.1109 /$ TIE.2006.878356

Ramki, T. and L.N. Tripathy, 2015. Comparison of different DC-DC converters for MPPT application of photovoltaic system. Proceedings of the International Conference on Electrical, Electronics, Signals, Communication and Optimization, Jun. 2425, IEEE Xplore Press, Visakhapatnam, India, pp: 1-6. DOI: 10.1109/EESCO.2015.7253764

Sheshadri, K.G., U.J. Shenoy, K. Parthasarathy, D. Thukaram and H.P. Kincha, 2004. MATLAB/PSB based modeling and simulation of $25 \mathrm{kV}$ AC railway traction system - a particular reference to loading and fault conditions. Proceedings of the IEEE Region 10 Conference, Nov. 24-24, IEEE Xplore Press, Chiang Mai, Thailand, pp: 508-511. DOI: 10.1109/TENCON.2004.1414819 
Thomas, R., Narayanappa and Thanushkodi, 2013. Reactive power compensation in electrical traction using active impedance concepts. Proceedings of the International Conference on Circuits, Power and Computing Technologies, Mar. 20-21, IEEE Xplore Press, Nagercoil, India, pp: 115-119. DOI: 10.1109/ICCPCT.2013.6529047

Tibor, B., V. Fedak and F. Durovsky, 2011. Modeling and simulation of the BLDC motor in MATLAB GUI. Proceedings of the IEEE International Symposium on Industrial Electronics, Jun. 27-30, IEEE Xplore Press, Gdansk, Poland, pp: 1403-1407. DOI: 10.1109/ISIE.2011.5984365

Vaishnav, C., V. Shrivastava and L. Singh, 2016. Performance analysis of hybrid network of Indian traction power system using renewable energy sources. Proceedings of the International Conference on Micro-Electronics and Telecommunication Engineering, Sept. 22-23, IEEE Xplore Press, Ghaziabad, India, pp: 611-615.

DOI: 10.1109/ICMETE.2016.101
Veeraraghavan, S., M. Kumaravel, K. Vasudevan and A. Jhunjhunwala, 2014. Experimental studies and performance evaluation of Solar PV powered BLDC motor drive with an integrated MPPT in fan applications. Proceedings of the 40th IEEE Photovoltaic Specialist Conference, Jun. 8-13, IEEE Xplore Press, Denver, CO, USA, pp: 3713-3718. DOI: 10.1109/PVSC.2014.6924912

Xuesong, Z., S. Daichun, M. Youjie and C. Deshu, 2010. The simulation and design for MPPT of PV system based on Incremental Conductance method. Proceedings of the WASE International Conference on Information Engineering, Aug. 14-15, IEEE Xplore Press, Beidaihe, Hebei, China, pp: 314-317. DOI: 10.1109/ICIE.2010.170 